\title{
The Impact of Probiotics in Respiratory Diseases
}

\author{
Rafee H. Askandar ${ }^{1 *}$, Nasim Ebrahimi² \\ ${ }^{1}$ Research Center, Sulaimani Polytechnic University, Sulaimani, Kurdistan Region, Iraq, ${ }^{2}$ Department Cell and Molecular Biology and \\ Microbiology, Division of Genetics, Faculty of Science and Technology, University of Isfahan, Isfahan, Islamic Republic of Iran
}

\author{
${ }^{*}$ Corresponding author: \\ Rafee H. Askandar, \\ Research Center, Sulaimani \\ Polytechnic University, \\ Sulaimani, Kurdistan Region, \\ Iraq. \\ E-mail: rafee.askandar@ \\ spu.edu.iq
}

Received: 14 November 2019

Accepted: 10 February 2020

Published: 30 June 2020

\section{DOI}

10.25156/pti.v10n1y2020.pp148-156

\section{A B S T R A C T}

Probiotics are viable microorganisms that, if adequately administered, confer great benefits to the host for the prevention or treatment of a wide range of human diseases, including recurrent respiratory tract infection (RRTI), cystic fibrosis, allergies, and chronic obstructive pulmonary disease (COPD). One of the current problems is that the overuse of antibiotics during respiratory tract infection has led to increased resistance to them, which has been demonstrated in numerous examinations that specific lactic acid bacteria (LAB), one of the key probiotics, against bacterial and viral infections of the respiratory and gastrointestinal tract, have a protective effect. On the other hand, changes in the gastrointestinal and respiratory microbiomes, especially lactobacilli and bifidobacteria, lead to an increase in allergies and asthma and a balance in the microbiome may improve symptoms. Probiotics are able to increase the number and activity of leukocytes, neutrophils, and NK cells. They can also increase IL-10 expression and decrease the expression of inflammatory cytokines such as TNF- $\alpha$, IL-1 $\beta$, and IL-8. In addition, they maintain high levels of IgA and produce bacteriocin and ruterin that have antimicrobial activity. Without identifying the specific properties of the probiotic strains and identifying the precise mechanism of their action, probiotic treatment would only be a large hypothesis because the therapeutic and clinical outcomes are different. On the other hand, metagenomics have provided information on how the microbiome interacts with host physiology, leading to new therapeutic targets.

Keywords: Lactic acid bacteria; Microorganism; Probiotics; Pulmonary disease; Respiratory disease

\section{INTRODUCTION}

According to a panel of international experts, probiotics are useful living microorganisms that, if adequately administered, provide the host with some health benefits (Hill et al., 2014; Joint, 2001). These bacteria often contain Lactobacillus and bifidobacteria and a wide range of nonpathogenic lactic acid bacteria (LAB) and E. coli (Forsythe 2011). Lactobacillus rhamnosus is a human-derived strain that has received the most studies among probiotics and has proven beneficial effects on respiratory disorders. Probiotics are widely added to dairy and food products and used as supplements (Siro et al., 2008). There is evidence to show how diet, bacteria, and their interactions with the immune system affect human health. For example, fecal microbial therapy (fecal microbiota transplantation [FMT]) in which transplants the microflora of a healthy person into a patient with ulcerative colitis (UC) suggests that the microbiome composition will play an important role in gastrointestinal infections and microbial repair can lead to an improvement in the disease. Properties of probiotics vary greatly depending on the strain, and even the strain production process affects its specific properties (Borody et al., 2004; D'souza et al., 2002; Salminen et al., 1998).

\section{Probiotics, Prevention, and Treatment}

Probiotics have so far been used to prevent or treatment a wide range of human diseases including antibioticdependent diarrhea, inflammatory bowel disease following surgical treatment (Salminen et al., 1998), recurrent respiratory tract infection (RRTI) that is one of the most prominent causes of child mortality in the world, especially in children younger than 2 years ( $\mathrm{Li}$ et al., 2019), cystic fibrosis (Anderson et al., 2017), inflammatory bowel problems such as IBD and IBS, allergy and Clostridium difficile (Goldenberg et al., 2017), chronic obstructive pulmonary disease (COPD) (Carvalho et al., 2019), nerve inflammation in animal models, reduce pain caused by inflammation, infection reduction, disease symptom reduction, reduce the duration of illness (Morimoto et al., 2005; Oelschlaeger, 2010; Rao et al., 2009), urinary tract infection reduction, autoimmune disease reduction, and reduced crying time in infants with colic (Dinleyici et al., 2015; Savino et al., 2010).

\section{Probiotics in Asthma and Allergy}

The rise in allergic diseases is a major worldwide concern (Peat et al., 1994). Due to the use of antibiotics and altered dietary plans in industrialized countries, immunological tolerance mechanisms in the mucosa are disrupted, leading 
to an increase in allergic diseases such as asthma. The first statistics in developed countries such as Australia, West Europe, and North America shows that $40 \%$ of the population has asthma, which is alarming for more people around the world because of the rapid urbanization (Noverr and Huffnagle, 2005). Various hypotheses have been proven that alterations in the gastrointestinal and respiratory microbiomes, especially lactobacilli and bifidobacteria, lead to increased allergies and asthma. The results of clinical trials suggest that feeding mothers with LABs, such as Lactobacillus rbamnosus and fermentum during pregnancy and early parturition, may be effective in the treatment and prevention of primary atopic diseases in children (Asher et al., 2006).

\section{The Mechanism of Action}

Although the exact mechanism of the anti-allergic activity of these bacteria is still unclear, there are potential hypotheses for these types of responses. Asthma is an inflammatory disease mediated by $\mathrm{T}$ lymphocytes which are transmitted from one mucosa to another and are often involved with the mucosal immune system. Probiotics can balance the response of $\mathrm{T}$ cells, leading to a decrease in Th2 activity. There is also evidence from model systems that probiotics can induce Treg cell class, thereby reducing Th1 and Th2 responses, which may be an important factor in the anti-inflammatory activity of many probiotics (Forsythe, 2011). LABs can induce systemic responses that do not require Treg to be exposed to specific allergens. On the other hand, although probiotic-mediated Tregs have important effects on immune regulation, functional changes in dendritic cells (DCs) following the use of probiotics, especially the ability to induce IL-10 production, are one of the important reasons for these responses (Foligne et al., 2007). Another study in an asthmatic mouse model has shown that consumption of Lactobacillus reuteri and Bifidobacterium reduces the overreactivity of the airways, the number of inflammatory cells in the bronchoalveolar lavage (BAL) fluid, and inflammation of the lung tissue (Feleszko et al., 2007; Hougee et al., 2010). In addition, probiotics improve the function of the gastrointestinal mucosal barriers, thereby reducing the release of antigens through the mucosa. On the other hand, probiotics directly stimulate the immune system and induce the production of anti-inflammatory cytokines, increasing the production of secretory IgA. Through activation of Treg cells and the activation of Th1, Th2, and Th12 cells, or changes in macrophage function, lead to a decrease in allergic responses. For example, Salva et al. showed that after consumption of $\mathrm{LAB}$, the profile of BAL cytokines changes, the number and activity of phagocyte cells, and the level of specific antibodies against allergens in serum and BAL increase (Salva et al., 2010).

\section{Probiotics and Respiratory Infections}

Attention to the gut microbiome has increased in recent decades, as it is associated with improved health and in some cases with increased risk and persistence of some diseases. The immune system can be directly or indirectly regulated by the gut bacteria by increasing levels of extracellular $\mathrm{T}$ cells, short-chain fatty acids, increasing drug tolerance, or controlling inflammation (Samuelson et al., 2015). Upper respiratory tract infections (URIs) caused by viruses are common health problems in the human body that burden society, including the need for health care, absenteeism, reduced school focus, and increased medical costs. Another problem is that the overuse of antibiotics in the treatment of respiratory tract infections has led to increased resistance to antibiotics (Roca et al., 2015). The need for new and improved strategies to cope with these diseases has led to the study of the therapeutic potential of symbiotic bacteria that induce mucosal immune responses. Numerous experiments have shown that specific LABs have a protective effect against bacterial and viral infections of the respiratory and digestive systems (Goldin and Gorbach, 2008). For example, the use of probiotics is associated with a decrease in pneumonia and viral and bacterial respiratory infections in children, leading to a decrease in the duration of the common cold infection. Therefore, there is a need to focus on identifying microorganisms that are capable of reducing viral infections early in life (Hatakka et al., 2001; Hojsak et al., 2010). The nasopharyngeal and adenoid microbiome is a complex interactive system that the cause of their altered properties is still unknown, such as probiotic colonization. The nasopharynx has a variety of bacteria and viruses (symbiosis and pathogens) that its microbiome composition differs from that of other parts of the body. The nasopharyngeal microbiome is potentially invasive, such as Streptococcus pneumoniae, Haemophilus influenzae, Staphylococcus aureus, Moraxella catarrbalis, and Neisseria meningitidis. In children, the nasopharyngeal microbiome changes according to the season and its coexisting cells are associated with pathogens of AOM (acute otitis media) and cause infectious diseases in children, and the characteristics of these strains change with antibiotic use (Pettigrew et al., 2011) and complex interactions between viruses and epithelium nasopharyngeal bacteria can lead to the formation of superinfectious bacteria. It is thought that the nasopharyngeal microbiome composition may be effective in protecting against respiratory infections. As a challenge test, there was a significant difference in the two genera of nasopharynx (Propionibacterium and Neisseria) in infected and uninfected individuals with human rhinovirus (Allen et al., 2014). Interestingly, the nasopharyngeal microbiome was studied in 60 healthy 
children, and it was found that the microbial pattern of the microbiome was associated with a decrease in URI (Biesbroek et al., 2014). On the other hand, the nasopharyngeal microbiome, especially Streptococcus, is associated with an increased risk of asthma in children (Teo et al., 2015), which is why breastfeeding is recommended because microbial diversity must be safeguarded (Berrington et al., 2014; Hojsak et al., 2010).

\section{Respiratory Bacterial Infections and Probiotics}

By preventing URIs and recurrent respiratory tract infections (RRTIs), which is one of the most common causes of hospitalized children (Gentile et al., 2012), the costs of treatment can be reduced using probiotics that have been studied in several cases (de Araujo et al., 2015). Probiotics have been shown to significantly reduce the risk of respiratory infections and can also be effective in treating cough, fever, and duration of antibiotic use (Liu et al., 2013; Rijkers et al., 2010; Vouloumanou et al., 2009). The following are some examples of the use of probiotics to treat respiratory infections.

The use of Lactobacillus rhamnosus GG (LGG) alone or in combination with other probiotics has led to a decrease in the prevalence of URI in children (Wong et al., 2013). On another study, LGG was reported to be able to block the binding of Streptococcus pneumoniae to human epithelial cells, indicating that specific probiotics interact with the pathogens and could potentially reduce the colonization of pathogens in the nasopharynx. According to an epidemiological study, the incidence of RRTI in China is approximately $20 \%$, which in children can increase the risk of chronic respiratory diseases in adulthood and cause permanent lung injury (Chen et al., 2009; Gentile et al., 2012).

On another study, Bifidobacterium tetraoxane tablets containing four strains (Bifidobacterium infantis, Lactobacillus acidophilus, Enterococcus faecalis, and Bacillus cereus) were used to treatment children with RRTI. The first three strains are the major probiotics of the gut and the cereus groups provide growth conditions for the first three strains by consuming oxygen and creating an anaerobic environment. Children with RRTI suffer from intestinal microbial flora imbalances, and the number of bifidobacteria and lactobacilli has been shown to be significantly reduced and the number of E. coli increased, as well as the number of bifidobacteria in the active stage of the disease is lower than the recovery stage. After treatment with tetravaccine tablets, the number of Bifidobacterium and Lactobacillus increased significantly and microbial balance was established in the gut. The mechanism of action is that the innate immunity of the lung tissue against external infections originates from the intestinal flora through NOD-like receptors (NLRs), as well as the intestinal probiotics regulate IgA production by pulmonary dendritic cells (Clarke, 2014). These probiotics also increase host resistance to pneumococcal pneumonia and aureus-derived pneumonia, as animal experiments have shown that non-probiotic mice have a significant defect in pulmonary clearance of Klebsiella pneumoniae (Brown and Clarke, 2017; Gauguet et al., 2015).

Another study found that probiotics are able to increase the number and activity of leukocytes, neutrophils, and NK cells. They can also increase IL-10 expression and the expression of inflammatory cytokines such as TNF- $\alpha$, IL-1 $\beta$, and IL-8. In addition, they maintain high levels of $\operatorname{IgA}$ and produce bacteriocin and rutin, which have antimicrobial activity (King et al., 2014; Oliva et al., 2012) [Figure 1].

In another example, immune stimulation was induced by Lactobacillus rhamnosus (Lr05) and (Lr06), and the resistance to respiratory pathogens such as Streptococcus pneumoniae and gastrointestinal pathogens such as Salmonella typhimurium led to a significant decrease in Th1 (INF- $\gamma$ ) and Th2 (IL-6, IL-4, IL-10) in BAL (Salva et al., 2010). In a subsequent study, Lactobacillus case $i$ was administered for 2 days, with results that increased Pseudomonas aeruginosa outflow from the lungs, increased alveolar macrophage phagocytic activity, and increased IgA levels in BAL fluid (Alvarez et al., 2001). The results of casei administration for 4 months were as follows: Decreased bacterial viability in nasal wash, increased splenic natural killer cell activity, and nasal passage mononuclear cells, increased production of INF-Q and TNF-K by mitogen-stimulated nasal lymphocytes (Hori et al., 2002). Koizumi et al. have shown that the treatment of mice with Lactobacillus pentosus enhances NK cell activity in the spleen and stimulates NKT and NK1.1-NK ${ }^{+}$cells to produce INF- $\gamma$ (Koizumi et al., 2008). Recently, Lactobacillus salivarius and Lactobacillus fermentum strains have been shown to enhance the innate and acquired immune response by activating NK cells and developing Tregs (Perez-Cano et al., 2010). Bifidobacterium infantis also induces Foxp ${ }^{3+} \mathrm{T}$ cells, which protects mice from infection with Salmonella typhimurium (O’Mahony et al., 2008). Thus, there are two branches of the immune system in which LABs participate and induce protection against respiratory pathogens. In addition, a number of LABs, such as Lactobacillus plantarum, are capable of producing antibacterial compounds that inhibit the induction of virulence factors in Pseudomonas aeruginosa (Sanz et al., 2007; Valdez et al., 2005) [Figure 2].

A summary of examples of the use of probiotics in the treatment of respiratory diseases is given in Table 1. 


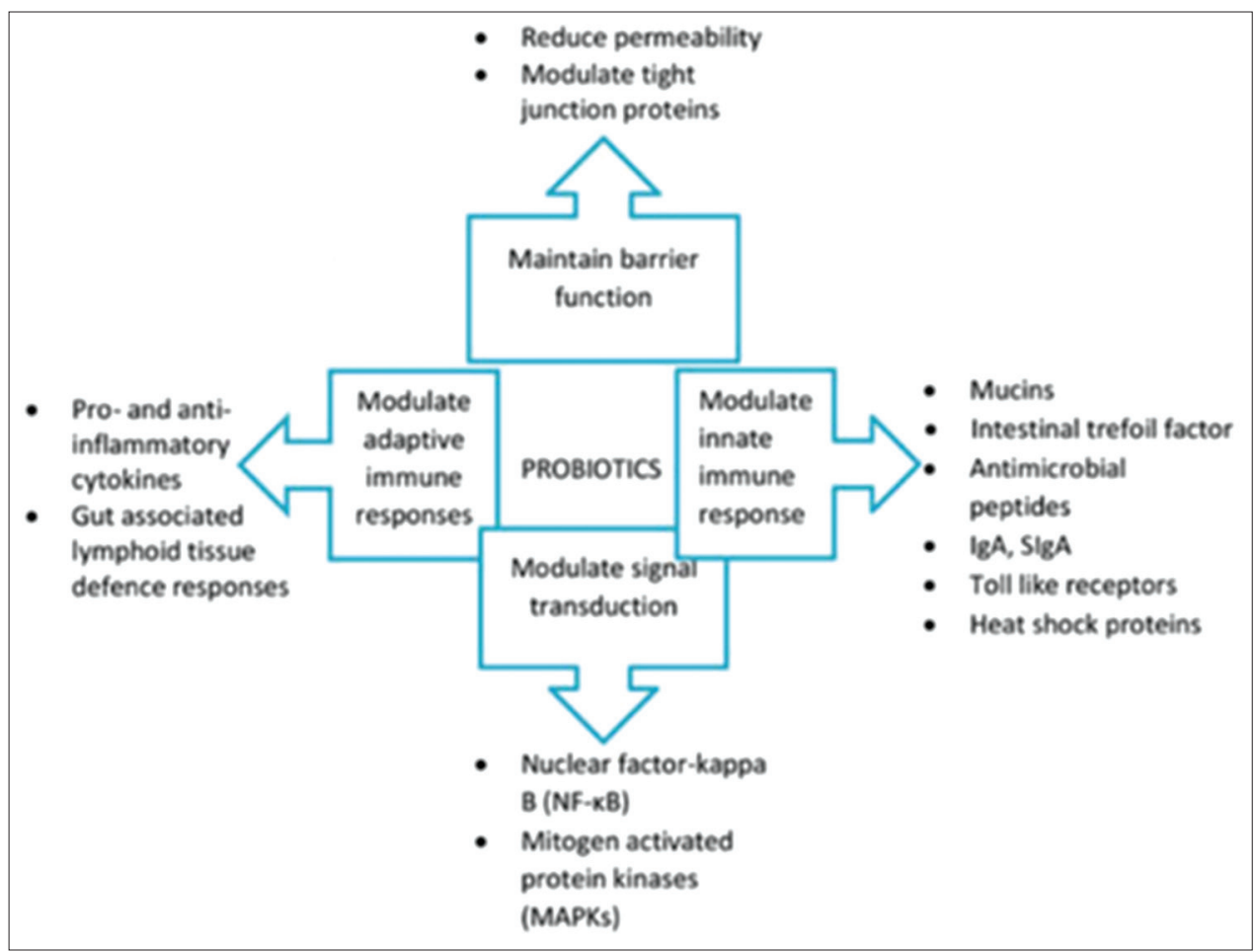

Figure 1: Possible mechanisms by which probiotic Streptococcus pneumoniae bacteria modulate the intestinal defense responses (Tapiovaara et al., 2016a)

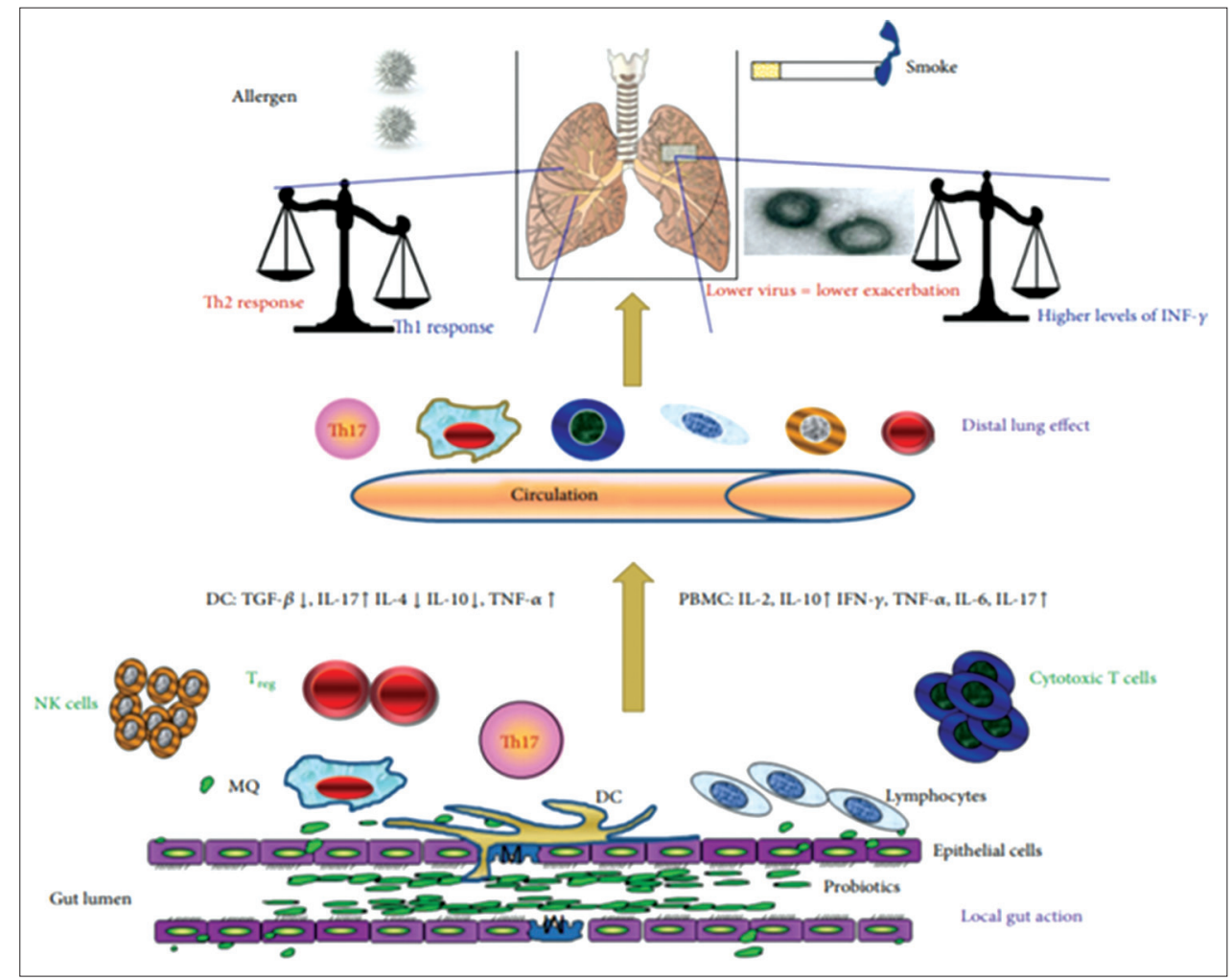

Figure 2: The gut can modulate airway immunity, but it may reflect changes in blood and local immune cells, including T cell subsets (Mortaz et al., 2013)

\section{Chronic Pulmonary Diseases and Probiotics}

Chronic obstructive pulmonary disease (COPD) is currently the fourth leading cause of death worldwide and is expected to become the third factor in the next 10 years. Smoking is one of the risk factors for COPD and lung cancer (Rabe et al., 2007; Wu et al., 2018). 
Table 1: Examples of the use of probiotics in the treatment of respiratory diseases

\begin{tabular}{|c|c|c|}
\hline Subject & Results & References \\
\hline $\begin{array}{l}\text { The effect of probiotic yogurt on exercise } \\
\text { performance, respiratory infections, and } \\
\text { gastrointestinal disorders in endurance } \\
\text { swimmers }\end{array}$ & $\begin{array}{l}\text { Use of probiotic yogurt reduced the number of respiratory infections } \\
\text { and reduced the duration of some symptoms such as wheezing and } \\
\text { earache }\end{array}$ & $\begin{array}{l}\text { Mortaz et al., } \\
\text { 2013, Gerritsen } \\
\text { et al., } 2016\end{array}$ \\
\hline $\begin{array}{l}\text { Use of four strains of Bifidobacterium } \\
\text { tetravaccine (Bifidobacterium infantis, } \\
\text { Lactobacillus acidophilus, Enterococcus } \\
\text { faecalis, and Bacillus cereus) for the treatment } \\
\text { of children with RRTI }\end{array}$ & $\begin{array}{l}\text { After treatment with tetravaccine tablets, the number of Bifidobacterium } \\
\text { and Lactobacillus was significantly increased and microbial balance } \\
\text { was established in the gut, and these probiotics also increased host } \\
\text { resistance to pneumococcal pneumonia and aureus pneumonia }\end{array}$ & $\begin{array}{l}\text { Schuijt et al., } \\
2016, \text { Gauguet } \\
\text { et al., } 2015\end{array}$ \\
\hline $\begin{array}{l}\text { The effect of Lactobacillus rhamnosus on } \\
\text { modulating the immune system response and } \\
\text { reducing respiratory diseases }\end{array}$ & $\begin{array}{l}\text { Resistance to respiratory pathogens such as Streptococcus } \\
\text { pneumoniae and gastrointestinal pathogens such as Salmonella } \\
\text { typhimurium, dramatic decrease in Th1 (INF- } \gamma \text { ) and Th2 (IL-6, } \\
\text { IL-4, and IL-10) in BAL }\end{array}$ & Salva et al., 2010 \\
\hline $\begin{array}{l}\text { Increased cellular immunity and decreased } \\
\text { titers of influenza virus in mice fed } \\
\text { Lactobacillus casei }\end{array}$ & $\begin{array}{l}\text { Consumption of Lactobacillus casei for } 2 \text { days increased Pseudomonas } \\
\text { aeruginosa outflow, increased alveolar macrophage phagocytosis } \\
\text { activity, and increased IgA levels in BAL fluid. Casein administration } \\
\text { for } 4 \text { months resulted in decreased bacterial viable titers in nasal wash, } \\
\text { increased spleen NK activity, and nasal passage mononuclear cells, } \\
\text { increased production of INF Q and TNF K by mitogen-stimulated nasal } \\
\text { lymphocytes }\end{array}$ & Hori et al., 2002 \\
\hline $\begin{array}{l}\text { Induced regulatory } T \text { cells, protective against } \\
\mathrm{NF}-\kappa B \text { stimulating pathogens }\end{array}$ & $\begin{array}{l}\text { Bifidobacterium infantis induces Foxp3 T cells, which protects mice } \\
\text { from infection with Salmonella typhimurium }\end{array}$ & $\begin{array}{l}\text { O’Mahony et al., } \\
2008\end{array}$ \\
\hline \multirow[t]{2}{*}{$\begin{array}{l}\text { Oral nutrition of Lactobacillus rhamnosus in } \\
\text { COPD and cigarette smoking rats }\end{array}$} & $\begin{array}{l}\text { Feeding with Lactobacillus rhamnosus increased IL-10 levels in BALF } \\
\text { and SOCS } 3 \text { in lung tissue compared to controls. }\end{array}$ & \multirow[t]{2}{*}{$\begin{array}{l}\text { Carvalho et al., } \\
2019\end{array}$} \\
\hline & $\begin{array}{l}\text { Probiotics induce an anti-inflammatory state, and rhamnosus enhances } \\
\text { mRNA levels for TLRS (one of the most important sites in COPD- } \\
\text { induced CS [smokers]) and pro-inflammatory transcription factors such } \\
\text { as NFKB and STAT3 compared to controls. At an acceptable level }\end{array}$ & \\
\hline $\begin{array}{l}\text { The effect of probiotics on prevention of } \\
\text { common cold }\end{array}$ & Probiotics have a moderate effect on reducing colds & $\begin{array}{l}\text { Lehtoranta et al., } \\
\text { 2012, Tapiovaara } \\
\text { et al., } 2016\end{array}$ \\
\hline $\begin{array}{l}\text { Probiotics in the management of pulmonary } \\
\text { diseases }\end{array}$ & Probiotics have no effect on asthma & Mortaz et al., 2013 \\
\hline
\end{tabular}

Probiotics reduce COPD-related cytokines and balance transcription factors that regulate the production of pro- and anti-inflammatory molecules. They also transmit inflammatory cells to the lungs and regenerate lung tissue, such as alveolar enlargement, increased collagen deposition, and mucus secretion in the lung. Nutrition with Lactobacillus rhamnosus increased IL10 levels in bronchoalveolar lavage fluid (BALF) and suppressor of cytokine signaling-3 (SOCS3) in lung tissue compared to controls. These findings indicate that probiotics induce an anti-inflammatory state and it has been hypothesized that L. rhamnosus enhances mRNA levels for Toll-like receptors (TLRs), one of the most important factors in COPD induced by smokers and that pro-inflammatory transcription factors such as NFKB and STAT3 are at acceptable levels compared to controls (Carvalho et al., 2019).

\section{Colonization of the Upper Respiratory Tract with Probiotics}

So far, little research has been done on the colonization of the upper respiratory tract with probiotics. Examples of these examinations, the type of probiotic supplement used, the duration of treatment, and the rate of colonization are presented in Table 2 (Tapiovaara et al., 2016a).

\section{Cystic Fibrosis (CF) Disease and Probiotics}

Cystic fibrosis (CF) is a genetic disease caused by a mutation in the fibrocystic transmembrane regulator gene that results in the deficiency or absence of CFTR proteins in the apical membrane of the gastrointestinal and respiratory epithelial cells (Li and Somerset, 2014). Disruption of the CFTR results in dehydration and mucus adhesion, which can cause inflammation and chronic infections and eventually destroys lung function (Li and Somerset, 2014; Rogers et al., 2010). Disorders in the gut microbiome can also cause many inflammatory diseases, including inflammatory bowel disease (IBD), irritable bowel syndrome (IBS), allergies, and airway inflammation (Gollwitzer and Marsland, 2014; Whelan and Quigley, 2013). Probiotics have a variety of ways to affect microbiome composition or function, host epithelial change, and immune responses and it has been suggested that in $\mathrm{CF}$, probiotics can help restore the intestinal microbial balance that has been used following repeated use of antimicrobial drugs to prevent and treat respiratory diseases (Rogers et al., 2010). 
Table 2: Examples of the examinations, the type of probiotic supplement used, the duration of treatment, and the rate of colonization

\begin{tabular}{|c|c|c|c|c|}
\hline Subject & $\begin{array}{l}\text { Design and length of } \\
\text { treatment }\end{array}$ & Probiotic supplement & Main findings & References \\
\hline $\begin{array}{l}\text { Healthy volunteers } \\
\text { Average age: } 38 \text { years } \\
\text { Number: } 6\end{array}$ & $\begin{array}{l}\text { Swab samples of } \\
\text { tonsils after each oral } \\
\text { absorption }\end{array}$ & L. plantarum $\left(2 \times 10^{11} \mathrm{cfu}\right)$ & $\begin{array}{l}\text { Stability of colonization } \\
\text { for } 8 \mathrm{~h}\end{array}$ & $\begin{array}{l}\text { Stjernquist- } \\
\text { Desatnik et al., } \\
2000\end{array}$ \\
\hline $\begin{array}{l}\text { Children scheduled for tympanostomy } \\
\text { Age: } 0.5-5 \\
\text { Number: } 19\end{array}$ & $\begin{array}{l}\text { Swab sample of tongue } \\
\text { and nasopharynx, } \\
10 \text { days }\end{array}$ & $\begin{array}{l}\text { S. salivarius } \mathrm{K} 12(1.7 \times \\
\left.10^{10} \mathrm{cfu}\right)\end{array}$ & $33 \%$ cloned & $\begin{array}{l}\text { Power et al., } \\
2008\end{array}$ \\
\hline $\begin{array}{l}\text { Young adults scheduled for } \\
\text { tonsillectomy } \\
\text { Average age: } 24.5 \\
\text { Number: } 57\end{array}$ & $\begin{array}{l}\text { RDBPC } \\
\text { tissue samples, } \\
3 \text { weeks }\end{array}$ & $\begin{array}{l}\text { LGG }\left(2 \times 10^{10} \mathrm{cfu}\right) \text { or } \\
\text { multispecies LGG, Lc705, } \\
\text { PJS, BB12 }\end{array}$ & $\begin{array}{l}30-40 \% \text { colonization } \\
\text { in different treatment } \\
\text { groups }\end{array}$ & $\begin{array}{l}\text { Kumpu et al., } \\
2013\end{array}$ \\
\hline $\begin{array}{l}\text { Healthy middle-aged adults } \\
\text { Age: } 54-30 \\
\text { Number: } 20\end{array}$ & $\begin{array}{l}\text { Nasal spray, } \\
\text { rhinopharyngeal swabs } \\
\text { for } 3 \text { days }\end{array}$ & $\begin{array}{l}\text { Salivarius } 24 \mathrm{SMBc} \\
\left(8 \times 10^{9} \mathrm{cfu}\right)\end{array}$ & $\begin{array}{l}95 \% \text { colonization, } 55 \% \\
\text { remaining for } 6 \text { days }\end{array}$ & $\begin{array}{l}\text { Santagati et al., } \\
2015\end{array}$ \\
\hline $\begin{array}{l}\text { Children scheduled for adenotomy } \\
\text { Mean age: } 37.8 \text { months } \\
\text { Number: } 31\end{array}$ & $\begin{array}{l}\text { RDBPC } \\
\text { Adenoid samples for } 3 \\
\text { weeks }\end{array}$ & LGG $\left(8-9 \times 10^{9} \mathrm{cfu}\right) \times 2 \mathrm{~S}$ & $\begin{array}{l}100 \% \text { colonized in } \\
\text { LGG group }\end{array}$ & $\begin{array}{l}\text { Swanljung et al., } \\
2015\end{array}$ \\
\hline $\begin{array}{l}\text { Children scheduled for tympanostomy } \\
\text { Mean age: } 31 \text { months } \\
\text { Number: } 13\end{array}$ & $\begin{array}{l}\text { RDBPC } \\
\text { MEE samples for } 3 \\
\text { weeks }\end{array}$ & LGG $\left(8-9 \times 10^{9}\right) \times 2$ & $\begin{array}{l}21 \% \text { colonization in } \\
\text { LGG group }\end{array}$ & $\begin{array}{l}\text { Tapiovaara et al., } \\
2014\end{array}$ \\
\hline
\end{tabular}

RDBPC: Randomized, placebo-controlled, prospective clinical trial

\section{CONCLUSIONS AND OUTLOOK}

According to the reports on the beneficial effects of probiotics on the treatment and prevention of respiratory diseases, however, there are still unsolved or ambiguous issues, some of which are outlined below.

It is not yet known which immune cells are the most important target for probiotic activity. In addition, there is currently no rational way to use probiotics for the treatment of pulmonary diseases. For select more effective strains or a combination of them in order to modulate immune response and treatment, we need more knowledge in the field of the gastrointestinal microbiome in patients with pulmonary disorders such as allergic diseases and even healthy neonates. For example, LAB strains differ in their ability to induce IL-2 in human dendritic cells (DCs) and consequently in DC cells producing DC-dependent INF- $\gamma$, therefore, the question of which strains of bacteria to use is still unclear (Harrington et al., 2005).

Because probiotics alter the composition or activity of the gastrointestinal microbiome, we need to obtain information about the culture of the gastrointestinal microbiome, not just the fecal samples (Mortaz et al., 2013). Although probiotic strains have a wide range of safety and therapeutic effects, there are reports that probiotics have no effect on asthma, which may be due to different observations. It is important to note that according to experiments by Kuitunen et al., the use of probiotic supplements by pregnant mothers and their protective effects from allergic diseases in their offspring are observed only in the type of cesarean delivery (Kuitunen et al., 2009).
In another trial, it has been reported that probiotic treatment can only be useful in the patient population (people with abnormal microbial flora). There is also conflicting information in this area, as reported in a study that the beneficial effect of probiotics in combination is less than either alone (Forsythe, 2011). While another study of the effect of traditional and industrial kefir on the secretion of $\operatorname{IgA}$ and $\operatorname{IgG}$ and modulating the immune response, it has been shown that a mixture of different strains (traditional kefir) is best used for treatment with probiotics (Davras et al., 2018). The therapeutic effects of probiotics may be related to the growth phase of the bacterium and there are few studies in which probiotic therapy has been performed for a long time. In a study of mice, it was found that the immunological effects of probiotics in the non-digestive system disappear with long-term treatment. Based on the findings, it is clear that without identifying the specific properties of the probiotic strains and identifying their exact mechanism of action, probiotic treatment would only be a large hypothesis because the clinical and therapeutic results are different (Forsythe, 2011). High-quality evidence is not currently available to suggest a specific species or strain of probiotics, the amount and duration of treatment (Forsythe, 2011). On the other hand, metagenomics has provided information on how the microbiome interacts with host physiology, leading to new therapeutic targets (Tapiovaara et al., 2016b). Concerning the safety of probiotics, this article states that LGG safety has been studied since 1989 with few reports of infection caused by probiotics such as bacteremia, endocarditis, and internal organ abscesses. These infections are very widespread and most people are at risk or affected by immune deficiencies (Salminen 
et al., 2002). As reported in Othman et al., 2008, there have been no reports of toxicity, adverse events, infection, and induction of resistance by probiotics in China so far. Therefore, if probiotics need to be used as a treatment, trials should be performed in several treatment centers and on a larger scale. Because reports of the benefits of probiotics in the treatment of respiratory problems vary in quality and may be at risk of being biased and the magnitude of the actual positive effect due to the diversity of individuals in the intervention and placebo groups is still unclear, more experiments are required. Given the differing views and statistics of the impact of probiotics on respiratory diseases, it is recommended that physicians use probiotics to treat respiratory diseases, since reports of effectiveness are more than reports of ineffectiveness. Furthermore, even if they are not effective, the probiotics will not cause any side effects for normal people because of the safety of probiotics.

\section{REFERENCES}

Allen, E. K., A. F. Koeppel, J. O. Hendley, S. D. Turner, B. Winther and M. M. Sale. 2014. Characterization of the nasopharyngeal microbiota in health and during rhinovirus challenge. Microbiome. 2: 22.

Alvarez, S., C. Herrero, E. Bru and G. Perdigon. 2001. Effect of Lactobacillus casei and yogurt administration on prevention of Pseudomonas aeruginosa infection in young mice. J. Food Protect. 64: 1768-1774.

Anderson, J. L., C. Miles and A. C. Tierney. 2017. Effect of probiotics on respiratory, gastrointestinal and nutritional outcomes in patients with cystic fibrosis: A systematic review. J. Cyst. Fibros. 16: 186-197.

Asher, M. I., S. Montefort, B. Björkstén, C. K. Lai, D. P. Strachan and S. K. Weiland. 2006. Worldwide time trends in the prevalence of symptoms of asthma, allergic rhinoconjunctivitis, and eczema in childhood: ISAAC phases one and three repeat multicountry cross-sectional surveys. Lancet. 368: 733-743.

Berrington, J. E., S. P. Cummings and N. D. Embleton. 2014. The nasopharyngeal microbiota: An important window of opportunity. Am. J. Respir. Crit. Care Med. 190: 246-248.

Biesbroek, G., E. Tsivtsivadze, E. A. Sanders, R. Montijn, R. H. Veenhoven and B. J. Keijser. 2014. Early respiratory microbiota composition determines bacterial succession patterns and respiratory health in children. Am. J. Respir. Cri. Care Med. 190: 1283-1292.

Borody, T. J., E. F. Warren, S. M. Leis, R. Surace, O. Ashman and S. Siarakas. 2004. Bacteriotherapy using fecal flora: Toying with human motions. J. Clin. Gastroenterol. 38: 475-483.

Brown. R. L. and T. B. Clarke. 2017. The regulation of host defences to infection by the microbiota. Immunology. 150: 1-6.

Carvalho, J. L., M. Miranda, A. K. Fialho, H. Castro-Faria-Neto, E. Anatriello and A. C. Keller. 2019. Oral feeding with probiotic Lactobacillus rhamnosus attenuates cigarette smoke-induced COPD in C57BI/6 mice: Relevance to inflammatory markers in human bronchial epithelial cells. BioRxiv. 2019: 843433.

Chen, J., Z. Xu, X. Ou, M. Wang, X. Yang and Q. Li. 2009. Mannosebinding lectin polymorphisms and recurrent respiratory tract infection in Chinese children. Eur. J. Pediatr. 168: 1305-1313.
Clarke, T. B. 2014. Early innate immunity to bacterial infection in the lung is regulated systemically by the commensal microbiota via nod-like receptor ligands. Infect. Immun. 82: 4596-4606.

D'souza, A. L., C. Rajkumar, J. Cooke and C. J. Bulpitt. 2002. Probiotics in prevention of antibiotic associated diarrhoea: Metaanalysis. BMJ. 324: 1361.

Davras, F., Z. B. Guzel-Seydim and T. K. Tas. 2018. Immunological effects of Kefir produced from Kefir grains versus starter cultures when fed to mice. Funct. Foods Health Dis. 8: 412-423.

de Araujo G. V., M. H. de Oliveira Junior, D. M. Peixoto and E. S. C. Sarinho. 2015. Probiotics for the treatment of upper and lower respiratory-tract infections in children: Systematic review based on randomized clinical trials. J. Pediatr. 91: 413-427.

Dinleyici, E. C., N. Dalgic, S. Guven, O. Metin, O. Yasa and Z. Kurugol. 2015. Lactobacillus reuteri DSM 17938 shortens acute infectious diarrhea in a pediatric outpatient setting. J. Pediatr. 91: 392-396.

Feleszko, W., J. Jaworska, R. D. Rha, S. Steinhausen, A. Avagyan and A. Jaudszus. 2007. Probiotic-induced suppression of allergic sensitization and airway inflammation is associated with an increase of $\mathrm{T}$ regulatory-dependent mechanisms in a murine model of asthma. Clin. Exp. Allergy. 37: 498-505.

Foligne, B., G. Zoumpopoulou, J. Dewulf, A. B. Younes, F. Chareyre and J. C. Sirard. 2007. A key role of dendritic cells in probiotic functionality. PLoS One. 2: e313.

Forsythe, P. 2011. Probiotics and lung diseases. Chest. 139: 901-908.

Gauguet, S., S. D'Ortona, K. Ahnger-Pier, B. Duan, N. K. Surana and R. Lu. 2015. Intestinal microbiota of mice influences resistance to Staphylococcus aureus pneumonia. Infect. Immun. 83: 40034014.

Gentile, A., A. Bardach, A. Ciapponi, S. Garcia-Marti, P. Aruj and D. Glujovsky. 2012. Epidemiology of community-acquired pneumonia in children of Latin America and the Caribbean: A systematic review and meta-analysis. Int. J. Infect. Dis. 16: e5-e15.

Goldenberg, J. Z., C. Yap, L. Lytvyn, C. K. F. Lo, J. Beardsley and D. Mertz. 2017. Probiotics for the prevention of Clostridium difficile-associated diarrhea in adults and children. Cochrane Database Syst. Rev. 12(12): CD006095.

Goldin, B. and S. Gorbach. 2008. Clinical indications for probiotics: An overview. Clin. Infect. Dis. 46: S96-S100.

Gollwitzer, E. S. and B. J. Marsland. 2014. Microbiota abnormalities in inflammatory airway diseases-potential for therapy. Pharmacol. Ther. 141: 32-39.

Harrington, L. E., R. D. Hatton, P. R. Mangan, H. Turner, T. L. Murphy and K. M. Murphy. 2005. Interleukin 17-producing CD4+ effector $\mathrm{T}$ cells develop via a lineage distinct from the T helper Type 1 and 2 lineages. Nat. Immunol. 6: 1123.

Hatakka, K., E. Savilahti, A. Pönkä, J. H. Meurman, T. Poussa and L. Näse. 2001. Effect of long term consumption of probiotic milk on infections in children attending day care centres: Double blind, randomised trial. BMJ. 322: 1327.

Hill, C., F. Guarner, G. Reid, G. R. Gibson, D. J. Merenstein and B. Pot. 2014. Expert consensus document: The international scientific association for probiotics and prebiotics consensus statement on the scope and appropriate use of the term probiotic. Nat. Rev. Gastroenterol. Hepatol. 11: 506.

Hojsak, I., S. Abdović, H. Szajewska, M. Milošević, Ž. Krznarić and S. Kolaček. 2010. Lactobacillus GG in the prevention of nosocomial gastrointestinal and respiratory tract infections. Pediatrics. 125: e1171-e1177.

Hori, T., J. Kiyoshima, K. Shida and H. Yasui. 2002. Augmentation of cellular immunity and reduction of influenza virus titer in aged 
mice fed Lactobacillus casei strain Shirota. Clin. Diagn. Lab. Immunol. 9: 105-108.

Hougee, S., A. Vriesema, S. Wijering, L. Knippels, G. Folkerts and F. Nijkamp. 2010. Oral treatment with probiotics reduces allergic symptoms in ovalbumin-sensitized mice: A bacterial strain comparative study. Int. Arch. Allergy Immunol. 151: 107-117.

Joint, F. 2001. WHO Expert Consultation on Evaluation of Health and Nutritional Properties of Probiotics in Food Including Powder Milk with Live Lactic Acid Bacteria. World Health Organization, Córdoba, Argentina.

King, S., J. Glanville, M. E. Sanders, A. Fitzgerald and D. Varley. 2014. Effectiveness of probiotics on the duration of illness in healthy children and adults who develop common acute respiratory infectious conditions: A systematic review and meta-analysis. Br. J. Nutr. 112: 41-54.

Koizumi, S. I., D. Wakita, T. Sato, R. Mitamura, T. Izumo and H. Shibata. 2008. Essential role of toll-like receptors for dendritic cell and NK1. 1+ cell-dependent activation of type 1 immunity by Lactobacillus pentosus strain S-PT84. Immunol. Lett. 120: 14-19.

Kuitunen, M., K. Kukkonen, K. Juntunen-Backman, R. Korpela, T. Poussa and T. Tuure. 2009. Probiotics prevent IgE-associated allergy until age 5 years in cesarean-delivered children but not in the total cohort. J. Allergy Clin. Immunol. 123: 335-341.

Li, K. L., B. Z. Wang, Z. P. Li, Y. L. Li and J. J. Liang. 2019. Alterations of intestinal flora and the effects of probiotics in children with recurrent respiratory tract infection. World J. Pediatr. 2019: 1-7.

Li, L. and S. Somerset. 2014. The clinical significance of the gut microbiota in cystic fibrosis and the potential for dietary therapies. Clin. Nutr. 33: 571-580.

Liu, S., P. Hu, X. Du, T. Zhou and X. Pei. 2013. Lactobacillus rhamnosus GG supplementation for preventing respiratory infections in children: A meta-analysis of randomized, placebocontrolled trials. Indian Pediatr. 50: 377-381.

Morimoto, K., T. Takeshita, M. Nanno, S. Tokudome and K. Nakayama. 2005. Modulation of natural killer cell activity by supplementation of fermented milk containing Lactobacillus casei in habitual smokers. Prev. Med. 40: 589-594.

Mortaz, E., I. M. Adcock, G. Folkerts, P. J. Barnes, A. Paul Vos and J. Garssen. 2013. Probiotics in the management of lung diseases. Med. Inflamm. 2013: 10.

Noverr, M. C. and G. Huffnagle. 2005 The microflora hypothesis of allergic diseases. Clin. Exp. Allergy. 35: 1511-1520.

O'Mahony, C., P. Scully, D. O'Mahony, S. Murphy, F. O'Brien, A. Lyons, G. Sherlock, J. MacSharry, B. Kiely, F. Shanahan and L. O'Mahony. 2008 Commensal-induced regulatory T cells mediate protection against pathogen-stimulated NF-KB activation. PLoS Pathog. 4: e1000112.

Oelschlaeger, T. A. 2010. Mechanisms of probiotic actions-a review. Int. J. Med. Microbiol. 300: 57-62.

Oliva, S., G. Di Nardo, F. Ferrari, S. Mallardo, P. Rossi, G. Patrizi, S. Cucchiara and L. Stronati. 2012. Randomised clinical trial: The effectiveness of Lactobacillus reuteri ATCC 55730 rectal enema in children with active distal ulcerative colitis. Aliment. Pharmacol. Ther. 35: 327-334.

Othman, M., R. Agüero and H. C. Lin. 2008. Alterations in intestinal microbial flora and human disease. Curr. Opin. Gastroenterol. 24: $11-16$

Peat, J. K., R. H. Van Den Berg, W. F. Green, C. M. Mellis, S. R. Leeder and A. Wolcock. 1994. Changing prevalence of asthma in Australian children. BMJ. 308: 1591-1596.

Perez-Cano, F. J., H. Dong and P. Yaqoob. 2010. In vitro immunomodulatory activity of Lactobacillus fermentum CECT5716 and Lactobacillus salivarius CECT5713: Two probiotic strains isolated from human breast milk. Immunobiology. 215: 996-1004.

Pettigrew, M. M., J. F. Gent, R. B. Pyles, A. L. Miller, J. Nokso-Koivisto and T. Chonmaitree. 2011. Viral-bacterial interactions and risk of acute otitis media complicating upper respiratory tract infection. J. Clin. Microbiol. 49: 3750-3755.

Rabe, K. F., S. Hurd, A. Anzueto, P. J. Barnes, S. A. Buist, P. Calverley, Y. Fukuchi, C. Jenkins, R. Rodriguez-Roisin, C. van Weel and J. Zielinski. 2007. Global strategy for the diagnosis, management, and prevention of chronic obstructive pulmonary disease: GOLD executive summary. Am. J. Respir. Cri. Care Med. 176: 532-555.

Rao, A. V., A. C. Bested, T. M. Beaulne, M. A. Katzman, C. Iorio and J. M. Berardi. 2009. A randomized, double-blind, placebocontrolled pilot study of a probiotic in emotional symptoms of chronic fatigue syndrome. Gut Pathog. 1: 6.

Rijkers, G. T., S. Bengmark, P. Enck, D. Haller, U. Herz and M. Kalliomaki. 2010. Guidance for substantiating the evidence for beneficial effects of probiotics: Current status and recommendations for future research. J. Nutr. 140: 671S-676S.

Roca, I., M. Akova, F. Baquero, J. Carlet, M. Cavaleri and S. Coenen. 2015. The global threat of antimicrobial resistance: Science for intervention. New Microbes. New Infect. 6: 22-29.

Rogers, G. B., M. Carroll, L. Hoffman, A. Walker, D. Fine and K. Bruce. 2010. Comparing the microbiota of the cystic fibrosis lung and human gut. Gut Microbes. 1: 85-93.

Salminen, M. K., S. Tynkkynen, H. Rautelin, M. Saxelin, M. Vaara and P. Ruutu. 2002. Lactobacillus bacteremia during a rapid increase in probiotic use of Lactobacillus rhamnosus GG in Finland. Clin. Infect. Dis. 35: 1155-1160.

Salminen, S., C. Bouley, M. C. Boutron, J. Cummings, A. Franck and G. Gibson. 1998. Functional food science and gastrointestinal physiology and function. Br. J. Nutr. 80: S147-S171.

Salva, S., J. Villena and S. Alvarez. 2010. Immunomodulatory activity of Lactobacillus rhamnosus strains isolated from goat milk: Impact on intestinal and respiratory infections. Int. J. Food Microbiol. 141: 82-89.

Samuelson, D. R., D. A. Welsh and J. E. Shellito. 2015 Regulation of lung immunity and host defense by the intestinal microbiota. Front. Microbiol. 6: 1085.

Sanz, Y., I. Nadal and E. Sánchez. 2007. Probiotics as drugs against human gastrointestinal infections. Rec. Patents Anti Infect. Drug Discov. 2: 148-156.

Savino, F., L. Cordisco, V. Tarasco, E. Palumeri, R. Calabrese and R. Oggero. 2010. Lactobacillus reuteri DSM 17938 in infantile colic: A randomized, double-blind, placebo-controlled trial. Pediatrics. 126: e526-e533.

Siro. I., E. Kápolna, B. Kápolna and A. Lugasi. 2008. Functional food. Product development, marketing and consumer acceptance-a review. Appetite. 51: 456-467.

Tapiovaara, L., A. I. Pitkäranta and R. Korpela. 2016b. Probiotics and upper respiratory tract-a review. Pediatr. Infect. Dis. J. 1: 1-8.

Tapiovaara, L., A. Pitkaranta and R. Korpela. 2016a. Probiotics and the upper respiratory tract-a review. Pediatr. Infect. Dis. 1: 2573.

Teo, S. M., D. Mok, K. Pham, M. Kusel, M. Serralha and N. Troy. 2015. The infant nasopharyngeal microbiome impacts severity of lower respiratory infection and risk of asthma development. Cell Host Microbe. 17: 704-715.

Valdez, J., M. Peral, M. Rachid, M. Santana and G. Perdigon. 2005. Interference of Lactobacillus plantarum with Pseudomonas aeruginosa in vitro and in infected burns: The potential use 
of probiotics in wound treatment. Clin. Microbiol. Infect. 11: 472-479.

Vouloumanou, E. K., G. C. Makris, D. E. Karageorgopoulos and M. E. Falagas. 2009. Probiotics for the prevention of respiratory tract infections: A systematic review. Int. J. Antimicrob. Agents. 34: 197.

Whelan, K. and E. M. Quigley. 2013. Probiotics in the management of irritable bowel syndrome and inflammatory bowel disease. Curr. Opin. Gastroenterol. 29: 184-189.
Wong, S. S., Z. Q. Toh, E. M. Dunne, E. K. Mulholland, M. L. Tang and R. M. Robins-Browne. 2013. Inhibition of Streptococcus pneumoniae adherence to human epithelial cells in vitro by the probiotic Lactobacillus rhamnosus GG. BMC Res. Notes. 6: 135.

Wu, D. D., J. Song, S. Bartel, S. Krauss-Etschmann, M. G. Rots and M. N. Hylkema. 2018. The potential for targeted rewriting of epigenetic marks in COPD as a new therapeutic approach. Pharmacol. Ther. 182: 1-14. 